\title{
Resilience of Epiphytic Lichens to Combined Effects of Increasing Nitrogen and Solar Radiation
}

\author{
Lourdes Morillas $^{1, *}$, Javier Roales ${ }^{1,2} \mathbb{D}$, Cristina $\operatorname{Cruz}^{1}$ and Silvana Munzi ${ }^{1,3}(\mathbb{D}$ \\ 1 Centre for Ecology, Evolution and Environmental Changes, Faculdade de Ciências, Universidade de Lisboa, \\ Campo Grande, Bloco C2, 1749-016 Lisbon, Portugal; jroabat@upo.es (J.R.); cmhoughton@fc.ul.pt (C.C.); \\ ssmunzi@fc.ul.pt (S.M.) \\ 2 Departamento de Sistemas Físicos, Químicos y Naturales, Universidad Pablo de Olavide, Ctra. Utrera Km 1, \\ 41013 Seville, Spain \\ 3 Centro Interuniversitário de História das Ciências e da Tecnologia Faculdade de Ciências, Universidade de \\ Lisboa, Campo Grande, 1749-016 Lisbon, Portugal \\ * Correspondence: lmorillas@fc.ul.pt
}

Citation: Morillas, L.; Roales, J.; Cruz, C.; Munzi, S. Resilience of Epiphytic Lichens to Combined Effects of Increasing Nitrogen and Solar Radiation. J. Fungi 2021, 7, 333. https://doi.org/10.3390/jof7050333

Academic Editor: Pradeep K. Divakar

Received: 27 March 2021

Accepted: 22 April 2021

Published: 26 April 2021

Publisher's Note: MDPI stays neutral with regard to jurisdictional claims in published maps and institutional affiliations.

Copyright: (c) 2021 by the authors. Licensee MDPI, Basel, Switzerland. This article is an open access article distributed under the terms and conditions of the Creative Commons Attribution (CC BY) license (https:// creativecommons.org/licenses/by/ $4.0 /)$.

\begin{abstract}
Lichens are classified into different functional groups depending on their ecological and physiological response to a given environmental stressor. However, knowledge on lichen response to the synergistic effect of multiple environmental factors is extremely scarce, although vital to get a comprehensive understanding of the effects of global change. We exposed six lichen species belonging to different functional groups to the combined effects of two nitrogen $(\mathrm{N})$ doses and direct sunlight involving both high temperatures and ultraviolet (UV) radiation for 58 days. Irrespective of their functional group, all species showed a homogenous response to $\mathrm{N}$ with cumulative, detrimental effects and an inability to recover following sunlight, UV exposure. Moreover, solar radiation made a tolerant species more prone to $\mathrm{N}$ pollution's effects. Our results draw attention to the combined effects of global change and other environmental drivers on canopy defoliation and tree death, with consequences for the protection of ecosystems.
\end{abstract}

Keywords: nitrogen pollution; forest decay; global change; chlorophyll fluorescence; Fv / Fm ratio; mediterranean ecosystems

\section{Introduction}

In the last decade, there has been a growing awareness of forests worldwide being affected by severe decline and mortality driven by biotic and abiotic factors, probably a consequence of global change [1-3]. Particularly, in Mediterranean ecosystems located in southern Europe, a severe decline of Quercus suber and Quercus ilex has been detected since the early 1980s [4-7]. In a context where human-induced stressors (such as global warming, air pollutants, and invasive exotic species, among others) are weakening and predisposing trees to defoliation and death, there is a pressing need to understand how these changes can translate into disturbed ecosystem functioning [8]. Not only that but also how these changes can interact with other environmental stressors at local or intermediate scales, such as atmospheric pollutants. Nitrogen $(\mathrm{N})$ deposition is one of the most challenging drivers of global change in the study area, as $\mathrm{N}$ inputs in the Mediterranean Basin are expected to increase from $7 \mathrm{~kg} \mathrm{~N} \mathrm{ha}^{-1} \mathrm{yr}^{-1}$ of the mid-1990s to $12 \mathrm{~kg} \mathrm{~N} \mathrm{ha}^{-1} \mathrm{yr}^{-1}$ in 2050 [9]. Interactions between environmental changes could trigger complex responses subjected to important uncertainties $[10,11]$, which could be pivotal drivers of the ecosystem dynamics [12]. However, our understanding of the consequences of forest decline and its interactions with $\mathrm{N}$ deposition is constrained by the limited available tools for disentangling these ecological interactions.

Epiphytic lichens can have a large impact on forest dynamics (e.g., N, carbon (C), phosphorous (P), and water cycling) [13], and due to their ability to regulate canopy 
environments, can improve water use by plants [14]. Hence, changes in lichen communities could deeply affect other forest processes. To fully understand the implications of the interactive effect of forest decline and increased $\mathrm{N}$ inputs for ecosystem functioning, it becomes fundamental to assess their impacts on epiphytic lichens.

A direct consequence of tree defoliation and mortality is the substantial increase in light intensity and, therefore, temperature for epiphytic lichens inhabiting the bark and branches. Such alterations can have a strong effect on lichens, which are amongst the most sensitive organisms to environmental changes [15], providing meaningful ecological systems to model and foresee the response of other less sensitive organisms of the ecosystem $[16,17]$. These poikilohydric organisms are especially sensitive to climate $[15,18]$ and air pollution [19-21] because their physiology is tightly linked to their water status, and they lack mechanisms to control their water and nutrient contents [22]. For this reason, they have been considered as valuable ecological indicators of environmental factors such as temperature and $\mathrm{N}$ deposition $[15,21,23]$.

Lichen functional groups are defined as groups of species that respond in a similar way to specific environmental factors [24]. To attribute a species to a given functional group, researchers assess the data available in the literature (e.g., LIAS [25]; Nimis and Martellos [26]; United States Forest Service [27]), and this knowledge has frequently been used to support environmental policies [28]. Therefore, the scientific community has considered of pivotal relevance to keep knowledge about species used in monitoring surveys as detailed and updated as possible [21]. This has been the case for lichens used to identify $\mathrm{N}$ pollution status: Oligotrophic species are highly sensitive to $\mathrm{N}$ pollution, whereas nitrophytic species tolerate such conditions [16]. This way, for example, it is currently well documented that Evernia prunastri (L.) and species belonging to the genus Usnea are sensitive species that tend to be affected by increased $\mathrm{N}$ availability [29-32], while Xanthoria parietina (L.) is much more resilient to this pollutant $[16,30,31]$. Despite the great efforts to increase our knowledge on the lichen community response to specific environmental factors, there is great uncertainty on how lichens will respond to the synergistic effect of multiple environmental changes. In particular, the combined effect of exposure to solar irradiation and increasing $\mathrm{N}$ availability on lichens has never been studied. Similarly, there is very little information about the recovering capacity of lichens after exposure to stress and none about the above-mentioned factors. Filling these gaps is vital to get a comprehensive understanding of the potential effects of global change, not only on lichen communities but also on important ecosystem processes, which is required for the science-based establishment of environmental policies.

The aim of this research was to assess the combined effect of both increased solar exposure and increased $\mathrm{N}$ deposition on the physiological response of six epiphytic lichen species belonging to various functional groups in terms of solar radiation and $\mathrm{N}$ tolerance. We hypothesized that the physiological response of lichens to increased solar radiation would be modulated by the $\mathrm{N}$ addition treatment, meaning a lower vitality in $\mathrm{N}$-treated samples exposed to direct sunlight than in control ones. We also expected that the different species would respond differently to these environmental factors because of their adaptation strategies. Namely, we expected that the most tolerant species to each one of these environmental stressors would be the most resilient to their synergistic effect. Finally, we hypothesized that species belonging to more tolerant functional groups would show a higher capacity to recover after the stress exposure than sensitive species. To test our hypotheses, we used chlorophyll $a$ fluorescence as a sensitive but non-destructive method for assessing the response of photosynthetic organisms to environmental changes [33]. Understanding the response of these sensitive elements of ecosystems to multiple environmental stressors is a primary goal to improve the use of lichens as indicators for environmental protection and predict the potential consequences of global change on ecosystem functioning. 


\section{Materials and Methods}

\subsection{Lichen Sampling}

In spring 2020, samples of Xanthoria parietina, Ramalina lacera, Usnea sp., Flavoparmelia caperata, Parmotrema hypoleucinum, and Evernia prunastri were collected from a forest patch near Vila Franca de Xira, Portugal (191 m a.s.L., $38^{\circ} 58^{\prime} 29^{\prime \prime}$ N, $9^{\circ} 00^{\prime} 27^{\prime \prime} \mathrm{W}$ ). This site was devoid of important sources of pollution; however, it can receive low $\mathrm{N}$ deposition from local roads and agricultural areas. Whenever possible, lichens were collected whole by cutting the branch or removing the bark that acted as a substrate. Samples were then transported to the laboratory, where branches or bark were carefully cut in order to leave only the minimum necessary to support the lichen. Finally, lichens were carefully cleaned to remove any impurities. All lichens were stored at room temperature and were fully rehydrated before performing any measurements.

The Ecological Indicator Values (Table 1) established by Nimis and Martellos [26] were used in this study as a proxy of functional groups. This table shows categorical values ranging from 1 to 5 that represent the ecological situations regarding solar irradiation and eutrophication where these species can be found in nature. Although samples of Usnea were not identified to species, most species of this genus have very similar ecological requirements with high tolerance to solar radiation and high sensitivity to $\mathrm{N}$.

Table 1. Lichen's Ecological Indicator Values established by Nimis and Martellos (2020).

\begin{tabular}{ccc}
\hline Lichen Species & Solar Irradiation $\mathbf{~}^{\mathbf{1}}$ & Eutrophication $^{\mathbf{2}}$ \\
\hline Xanthoria parietina & $3,4,5$ & 3,4 \\
Ramalina lacera & 4,5 & 2,3 \\
Usnea sp. & 4,5 & 1,2 \\
Flavoparmelia caperata & 3,4 & $1,2,3$ \\
Parmotrema hypoleucinum & 4,5 & 1,2 \\
Evernia prunastri & $3,4,5$ & $1,2,3$ \\
\hline
\end{tabular}

${ }^{1}$ Values mean: 1 in very shaded situations, 2 in shaded situations, 3 in sites with plenty of diffuse light but scarce direct solar irradiation, 4 in sun-exposed sites, 5 in sites with very high direct solar irradiation. ${ }^{2}$ Values mean: 1 no eutrophication, 2 very weak eutrophication, 3 weak eutrophication, 4 rather high eutrophication, 5 very high eutrophication.

\subsection{Nitrogen Treatment}

Two levels of $\mathrm{N}$ treatment ( 25 and N 50) and a control were established. Treatments involved daily immersion of the samples in $25 \mathrm{mM}(\mathrm{N} 25)$ or $50 \mathrm{mM}(\mathrm{N} 50)\left(\mathrm{NH}_{4}\right)_{2} \mathrm{SO}_{4}$ solutions for 5 min repeated for 58 days. The same protocol was followed for control samples using only mineral water with low mineral content. It is worth noting that all species in this experiment have a trebouxioid photobiont, which requires alternate wetting and drying to get a photosynthetic response of the photobiont. Lichens were housed in custom-built wire mesh cages that prevented their flotation on the solutions (see Figure S1 in the Supplementary Materials). After each treatment, the samples were placed in wire mesh shelves in a well-aerated location, which ensured enough drying before the subsequent immersion and hence prevented rotting of the lichen thalli or the substrate (see Figure S2 in the Supplementary Materials). Mineral water with low mineral content was used to avoid osmotic shock. For each treatment, 5 replicates were used.

\subsection{Increased Radiation Treatment}

Light exposure treatment was undertaken in 3 stages in parallel with the $\mathrm{N}$ treatment. First, lichens were incubated indoors in front of a big north-facing window, with abundant light but no direct sun. This started the same day as the $\mathrm{N}$ treatment and lasted 20 days. The 2nd stage involved the daily exposure of the lichens to $5 \mathrm{~h}$ of direct sunlight during the hours of higher solar radiation (from 10 a.m. to 3 p.m., solar time). The average temperature during the exposure was $28^{\circ} \mathrm{C}$, and the maximum temperature was $35.8^{\circ} \mathrm{C}$, with sunny conditions throughout the exposure. The reported temperature was measured in the closest meteorological station, therefore, in shaded conditions. It should be noted that 
the temperature at the lichen surface, which was permanently facing the sun, was likely to exceed the measured air temperature considerably. This part of the treatment lasted 8 days and was performed in mid-May in southern Spain (42 $\mathrm{m}$ a.s.1., $37^{\circ} 16^{\prime} 51^{\prime \prime} \mathrm{N}, 5^{\circ} 54^{\prime} 54^{\prime \prime} \mathrm{W}$ ). After each sun exposure, lichens were returned indoors to avoid humidity or temperature fluctuations. In the last stage, intended as recovery, lichens were returned to the indoors location. The recovery lasted 29 days until the end of the experiment. No control group was established for this treatment because we intended to analyze the difference among $\mathrm{N}$ levels and not radiation levels.

\subsection{Chlorophyll a Fluorescence}

Treatment effects were quantified using a Plant Efficiency Analyzer Handy PEA (Hansatech Instruments LTD, Pentney, UK), which determined the Fv/Fm ratio, the most frequently used chlorophyll $a$ fluorescence parameter, vitality index in ecological research [34-36]. Ten minutes after each daily $\mathrm{N}$ treatment, with the samples fully rehydrated, the $\mathrm{Fv} / \mathrm{Fm}$ ratio was measured $[37,38]$. Lichens were dark-adapted at room temperature for 15 min to maximize oxidation of the primary quinone electron acceptor of PSII immediately before measuring fluorescence. For each treatment, 5 replicates were used.

\subsection{Statistical Analyses}

Data were checked for conformity with repeated measures ANOVA assumptions via Shapiro-Wilk normality test and Mauchly's test of sphericity. Normality tests of the residuals by time point revealed that they followed approximately a normal distribution. Sphericity could not be assured due to the number of samples being lower than the number of repeated measures, hence a Greenhouse-Geisser correction was used. Differences in $\mathrm{Fv} / \mathrm{Fm}$ values among $\mathrm{N}$ treated and control samples were evaluated via repeated measures procedure following a 2-way mixed ANOVA design with 1 within-subjects factor and 1 between-groups factor in IBM SPSS Statistics 23.0 (SPSS Inc., Chicago, IL, USA). Pairwise comparisons were performed by comparing main effects through post hoc tests using the Bonferroni correction. To investigate interactions, data were divided into subsets based on $\mathrm{N}$ treatments and then were subjected to repeated-measures analyses. The evolution following the recovery period was computed as the difference between Fv / Fm values at day 58 (final time) and Fv / Fm values at day 29 (end of the second stage of the radiation treatment). To test for differences in the ability to recover from the radiation treatment of the different $\mathrm{N}$ treatments, we performed 1-way ANOVA of the differences between $\mathrm{Fv} / \mathrm{Fm}$ values for all the studied epiphytic lichens.

\section{Results}

\subsection{Analyses of the Effect of $N$ Pollution}

Six measurements over the first 20 days assessed the effects of $\mathrm{N}$ pollution alone, while lichens were not subject to irradiation. Significant effects of the different N treatments and time for all species except Xanthoria were found (Figure 1 and Table 2). For all affected species, Fv/Fm values gradually dropped, responding to the cumulative effect of $\mathrm{N}$, especially the $50 \mathrm{~N}$ dose (Figure 1). In Evernia and Flavoparmelia there was no significant effect of the low $\mathrm{N}$ dose but a significant reduction with the high $\mathrm{N}$ dose compared with both the control and low $\mathrm{N}$ dose. In Parmotrema, Ramalina and Usnea, both $\mathrm{N}$ doses caused significant reductions, but the level of reduction between the $\mathrm{N}$ doses was statistically indistinguishable. Measurements of the control indicated there was no deterioration in the index due to time, i.e., the experimental conditions did not affect the measurements. However, with the $\mathrm{N}$ treatments, as the experimental duration progressed, the lichens received more $\mathrm{N}$, i.e., time also means a greater cumulative $\mathrm{N}$ dose. We detected significant differences between the control and $50 \mathrm{~N}$ and $25 \mathrm{~N}$ and $50 \mathrm{~N}$ but not between control and $25 \mathrm{~N}$ for Evernia ( $p_{\text {control-25 } \mathrm{N}}=0.960, p_{\text {control-50 } \mathrm{N}}<0.0005, p_{25 \mathrm{~N}-50 \mathrm{~N}}<0.0005$ ) and Flavoparmelia ( $\left.p_{\text {control-25 } \mathrm{N}}=0.534, p_{\text {control-50 N }}=0.001, p_{25 \mathrm{~N}-50 \mathrm{~N}}=0.009\right)$. These differences were also found among control and N-treated samples, both 25 and $50 \mathrm{~N}$, although not between 
them, for Parmotrema ( $p_{\text {control-25 } \mathrm{N}}=0.002, p_{\text {control-50 N }}=0.002, p_{25 \mathrm{~N}-50 \mathrm{~N}}=1.000$ ), Ramalina $\left(p_{\text {control-25 } \mathrm{N}}<0.0005, p_{\text {control-50 N }}<0.0001, p_{25 \mathrm{~N}-50 \mathrm{~N}}=1.000\right)$ and Usnea $\left(p_{\text {control-25 } \mathrm{N}}<0.0005\right.$, $\left.p_{\text {control-50 } \mathrm{N}}<0.0005, p_{25 \mathrm{~N}-50 \mathrm{~N}}=1.000\right)$. There was a significant $\mathrm{N}$ treatment $\times$ time interaction for Ramalina, Flavoparmelia, Usnea, and Evernia, and when looking into them, we found a significant effect of time for $25 \mathrm{~N}$ and $50 \mathrm{~N}$ treatments, but not for control for Ramalina, Usnea, and Evernia (Table 2). In the case of Flavoparmelia, we only detected a significant effect of time for $50 \mathrm{~N}$ (Table 2).
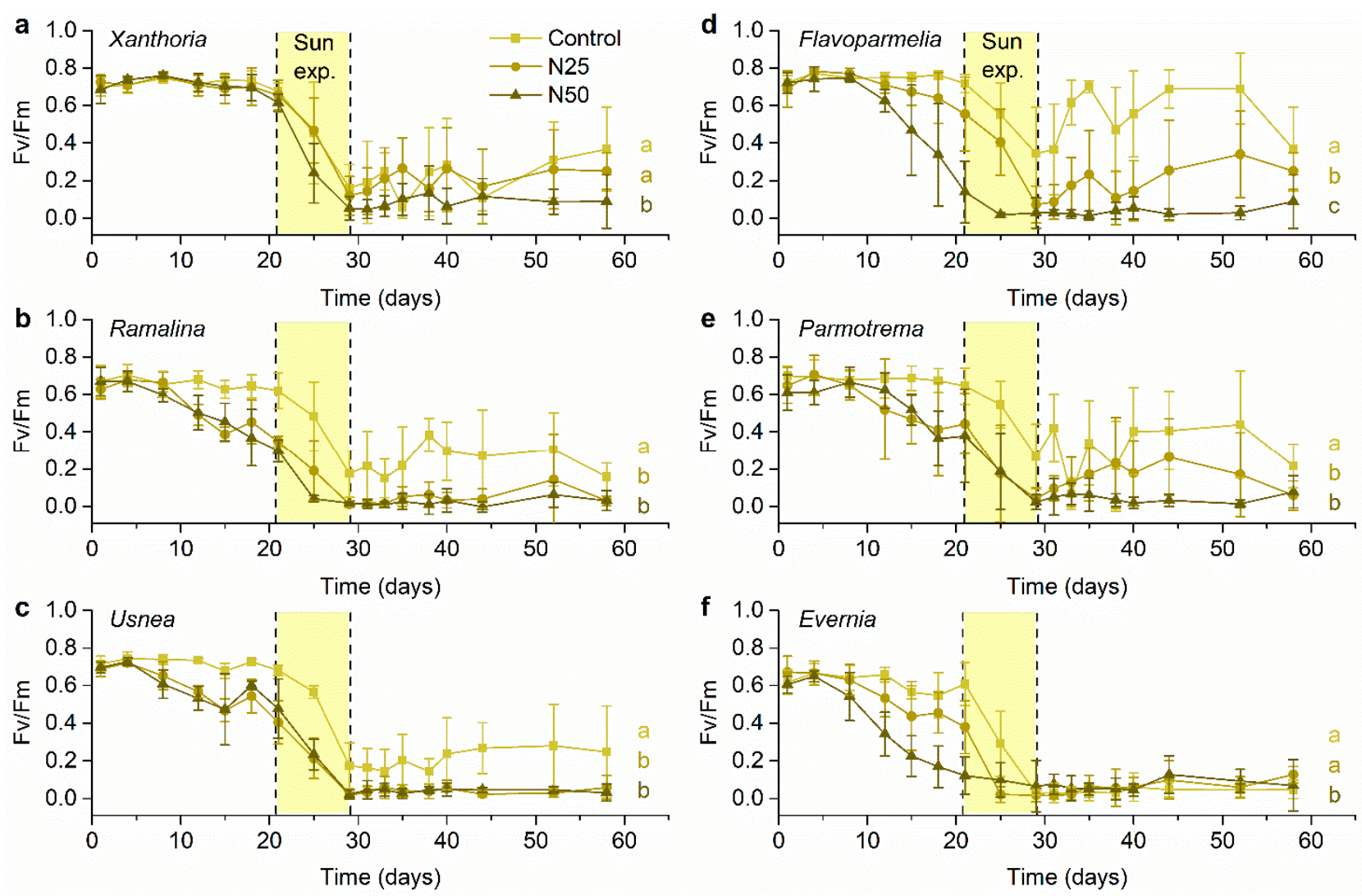

Figure 1. Temporal evolution of $\mathrm{Fv} / \mathrm{Fm}$ ratio during 58 days for Control (no nitrogen [N] addition), $25 \mathrm{~N}$ (treated with $25 \mathrm{mM}$ of $\left.\left(\mathrm{NH}_{4}\right)_{2} \mathrm{SO}_{4}\right)$ and $50 \mathrm{~N}$ (treated with $50 \mathrm{mM}$ of $\left.\left(\mathrm{NH}_{4}\right)_{2} \mathrm{SO}_{4}\right)$ for the following species: (a) Xanthoria parietina, (b) Ramalina lacera, (c) Usnea sp., (d) Flavoparmelia caperata, (e) Parmotrema hypoleucinum, (f) Evernia prunastri. All samples were subjected to the same radiation treatment. The period of exposure to direct sunlight is indicated in yellow. Lowercase letters indicate significant differences among $\mathrm{N}$ treatments for each species $(n=5)$.

Table 2. Repeated measures ANOVA analyses for all the studied epiphytic lichens during the first 20 days. The samples were subjected to $\mathrm{N}$ treatment alone during this period. Control = No nitrogen (N) addition, $25 \mathrm{~N}$ = treated with $25 \mathrm{mM}$ of $\left(\mathrm{NH}_{4}\right)_{2} \mathrm{SO}_{4}, 50 \mathrm{~N}=$ treated with $50 \mathrm{mM}$ of $\left(\mathrm{NH}_{4}\right)_{2} \mathrm{SO}_{4}$.

\begin{tabular}{ccccc}
\hline Lichen Species & Factor & df & F & $p$ \\
\hline Xanthoria parietina & N treatment & 2 & 0.198 & 0.823 \\
\hline & Time & 2.870 & 1.912 & 0.148 \\
\hline Ramalina lacera & N treatment $\times$ Time & 5.740 & 0.617 & 0.709 \\
\hline & N treatment & 2 & 23.679 & $<0.0005$ \\
\hline & Time & 2.707 & 20.028 & $<0.0005$ \\
\hline
\end{tabular}


Table 2. Cont.

\begin{tabular}{|c|c|c|c|c|}
\hline Lichen Species & Factor & df & $\mathbf{F}$ & $p$ \\
\hline Interaction $\mathrm{N}$ treatment $\times$ Time & Control & 1.999 & 0.920 & 0.437 \\
\hline Interaction $\mathrm{N}$ treatment $\times$ Time & $25 \mathrm{~N}$ & 1.369 & 17.619 & 0.005 \\
\hline Interaction $\mathrm{N}$ treatment $\times$ Time & $50 \mathrm{~N}$ & 2.247 & 9.150 & 0.006 \\
\hline \multirow[t]{3}{*}{ Usnea sp. } & $\mathrm{N}$ treatment & 2 & 22.354 & $<0.0005$ \\
\hline & Time & 2.418 & 19.147 & $<0.0005$ \\
\hline & $\mathrm{N}$ treatment $\times$ Time & 4.836 & 3.428 & 0.016 \\
\hline Interaction $\mathrm{N}$ treatment $\times$ Time & Control & 2.102 & 3.194 & 0.091 \\
\hline Interaction $\mathrm{N}$ treatment $\times$ Time & $25 \mathrm{~N}$ & 2.752 & 15.265 & $<0.0005$ \\
\hline Interaction $\mathrm{N}$ treatment $\times$ Time & $50 \mathrm{~N}$ & 1.458 & 6.499 & 0.038 \\
\hline \multirow[t]{3}{*}{ Flavoparmelia caperata } & $\mathrm{N}$ treatment & 2 & 14.098 & 0.001 \\
\hline & Time & 2.310 & 7.787 & 0.001 \\
\hline & $\mathrm{N}$ treatment $\times$ Time & 4.620 & 4.170 & 0.007 \\
\hline Interaction $\mathrm{N}$ treatment $\times$ Time & Control & 2.612 & 1.626 & 0.243 \\
\hline Interaction $\mathrm{N}$ treatment $\times$ Time & $25 \mathrm{~N}$ & 2.133 & 3.792 & 0.064 \\
\hline Interaction $\mathrm{N}$ treatment $\times$ Time & $50 \mathrm{~N}$ & 2.060 & 5.772 & 0.027 \\
\hline \multirow[t]{3}{*}{ Parmotrema hypoleucinum } & $\mathrm{N}$ treatment & 2 & 14.291 & 0.001 \\
\hline & Time & 3.032 & 5.077 & 0.005 \\
\hline & $\mathrm{N}$ treatment $\times$ Time & 6.064 & 1.531 & 0.195 \\
\hline \multirow[t]{3}{*}{ Evernia prunastri } & $\mathrm{N}$ treatment & 2 & 34.371 & $<0.0005$ \\
\hline & Time & 3.066 & 28.366 & $<0.0005$ \\
\hline & $\mathrm{N}$ treatment $\times$ Time & 6.132 & 5.988 & $<0.0005$ \\
\hline Interaction $\mathrm{N}$ treatment $\times$ Time & Control & 1.911 & 3.591 & 0.081 \\
\hline Interaction $\mathrm{N}$ treatment $\times$ Time & $25 \mathrm{~N}$ & 2.283 & 6.503 & 0.024 \\
\hline Interaction $\mathrm{N}$ treatment $\times$ Time & $50 \mathrm{~N}$ & 1.877 & 21.993 & 0.001 \\
\hline
\end{tabular}

\subsection{Analyses of the Synergetic Effect of $N$ and Solar Radiation}

We found a significant effect of the different $\mathrm{N}$ treatments on all lichen species when analyzing the synergetic effect of $\mathrm{N}$ and increased solar radiation (Figure 1 and Table 3 ). For all species, direct sun exposure dramatically decreased Fv/Fm (Figure 1), although these values reached their minimum earliest in $\mathrm{N}$ treated samples. Lichens exposed to $50 \mathrm{~N}$ treatment showed a consistent trend towards lower $\mathrm{Fv} / \mathrm{Fm}$ values for all species (Figure 1). We detected significant differences between the control and $50 \mathrm{~N}$ and $25 \mathrm{~N}$ and $50 \mathrm{~N}$ but not between control and $25 \mathrm{~N}$ for Xanthoria ( $p_{\text {control-25 N }}=1.000, p_{\text {control-50 N }}=0.003, p_{25 \mathrm{~N}-50 \mathrm{~N}}=0.009$ ) and Evernia ( $\left.p_{\text {control-25 }}=0.133, p_{\text {control-50 }}<0.0005, p_{25 \mathrm{~N}-50 \mathrm{~N}}=0.009\right)$. Differences were also found among control and N-treated samples, both 25 and $50 \mathrm{~N}$, although not between them, for Parmotrema $\left(p_{\text {control-25 N }}<0.0005, p_{\text {control-50 N }}<0.0005, p_{25 \mathrm{~N}-50 \mathrm{~N}}=0.072\right)$, Ramalina ( $p_{\text {control-25 N }}<0.0005, p$ control-50 N $\left.<0.0005, p_{25 \mathrm{~N}-50 \mathrm{~N}}=0.282\right)$ and Usnea ( $\left.p_{\text {control-25 } \mathrm{N}}<0.0005, p_{\text {control-50 } \mathrm{N}}<0.0005, p_{25 \mathrm{~N}-50 \mathrm{~N}}=1.000\right)$. We found significant differences among all the three groups (control, $25 \mathrm{~N}$ and $50 \mathrm{~N}$ ) for Flavoparmelia $\left(p_{\text {control-25 } \mathrm{N}}<0.0005, p\right.$ control-50 N $\left.<0.0005, p_{25 \mathrm{~N}-50 \mathrm{~N}}<0.0005\right)$. Time was found to significantly affect all analyzed lichens species (Figure 1 and Table 3). There was a significant $\mathrm{N}$ treatment $\times$ time interaction for Ramalina, Flavoparmelia, and Evernia, and when looking into them, we found a significant effect of time for the control, $25 \mathrm{~N}$ and $50 \mathrm{~N}$ treatments for all these species (Table 3). 
Table 3. Repeated measures ANOVA analyses for all the studied epiphytic lichens during the whole experiment. The samples were subjected to $\mathrm{N}$ treatment and solar radiation. Control $=$ No nitrogen (N) addition, $25 \mathrm{~N}$ = treated with $25 \mathrm{mM}$ of $\left(\mathrm{NH}_{4}\right)_{2} \mathrm{SO}_{4}, 50 \mathrm{~N}=$ treated with $50 \mathrm{mM}$ of $\left(\mathrm{NH}_{4}\right)_{2} \mathrm{SO}_{4}$.

\begin{tabular}{|c|c|c|c|c|}
\hline Lichen Species & Factor & df & $\mathbf{F}$ & $p$ \\
\hline \multirow[t]{3}{*}{ Xanthoria parietina } & $\mathrm{N}$ treatment & 2 & 10.769 & 0.002 \\
\hline & Time & 4.753 & 71.389 & $<0.0005$ \\
\hline & $\mathrm{N}$ treatment $\times$ Time & 9.505 & 1.230 & 0.293 \\
\hline \multirow[t]{3}{*}{ Ramalina lacera } & $\mathrm{N}$ treatment & 2 & 112.702 & $<0.0005$ \\
\hline & Time & 5.020 & 85.423 & $<0.0005$ \\
\hline & $\mathrm{N}$ treatment $\times$ Time & 10.039 & 2.083 & 0.040 \\
\hline Interaction $\mathrm{N}$ treatment $\times$ Time & Control & 3.381 & 12.826 & $<0.0005$ \\
\hline Interaction $\mathrm{N}$ treatment $\times$ Time & $25 \mathrm{~N}$ & 2.000 & 41.841 & $<0.0005$ \\
\hline Interaction $\mathrm{N}$ treatment $\times$ Time & $50 \mathrm{~N}$ & 2.786 & 80.237 & $<0.0005$ \\
\hline \multirow[t]{3}{*}{ Usnea sp. } & $\mathrm{N}$ treatment & 2 & 99.448 & $<0.0005$ \\
\hline & Time & 4.560 & 137.635 & $<0.0005$ \\
\hline & $\mathrm{N}$ treatment $\times$ Time & 9.119 & 1.527 & 0.164 \\
\hline \multirow[t]{3}{*}{ Flavoparmelia caperata } & $\mathrm{N}$ treatment & 2 & 372.020 & $<0.0005$ \\
\hline & Time & 5.163 & 36.500 & $<0.0005$ \\
\hline & $\mathrm{N}$ treatment $\times$ Time & 10.326 & 4.744 & $<0.0005$ \\
\hline Interaction $\mathrm{N}$ treatment $\times$ Time & Control & 2.369 & 4.875 & 0.031 \\
\hline Interaction $\mathrm{N}$ treatment $\times$ Time & $25 \mathrm{~N}$ & 2.545 & 13.058 & 0.001 \\
\hline Interaction $\mathrm{N}$ treatment $\times$ Time & $50 \mathrm{~N}$ & 2.425 & 37.915 & $<0.0005$ \\
\hline \multirow[t]{3}{*}{ Parmotrema hypoleucinum } & $\mathrm{N}$ treatment & 2 & 46.314 & $<0.0005$ \\
\hline & Time & 6.299 & 32.540 & $<0.0005$ \\
\hline & $\mathrm{N}$ treatment $\times$ Time & 12.598 & 1.629 & 0.098 \\
\hline \multirow[t]{3}{*}{ Evernia prunastri } & $\mathrm{N}$ treatment & 2 & 21.052 & $<0.0005$ \\
\hline & Time & 6.129 & 135.430 & $<0.0005$ \\
\hline & $\mathrm{N}$ treatment $\times$ Time & 12.258 & 7.621 & $<0.0005$ \\
\hline Interaction $\mathrm{N}$ treatment $\times$ Time & Control & 2.517 & 86.264 & $<0.0005$ \\
\hline Interaction $\mathrm{N}$ treatment $\times$ Time & $25 \mathrm{~N}$ & 2.663 & 59.673 & $<0.0005$ \\
\hline Interaction $\mathrm{N}$ treatment $\times$ Time & $50 \mathrm{~N}$ & 3.231 & 25.576 & $<0.0005$ \\
\hline
\end{tabular}

\subsection{Analyses of the Evolution Following the Recovery Period}

None of the studied species was able to recover following the solar radiation exposure (Figures 1 and 2). However, a non-significant trend of decreased ability to recover from solar radiation stress with increased $\mathrm{N}$ dose was found for Xanthoria, Usnea, and Flavoparmelia (Figure 2 and Table 4). 


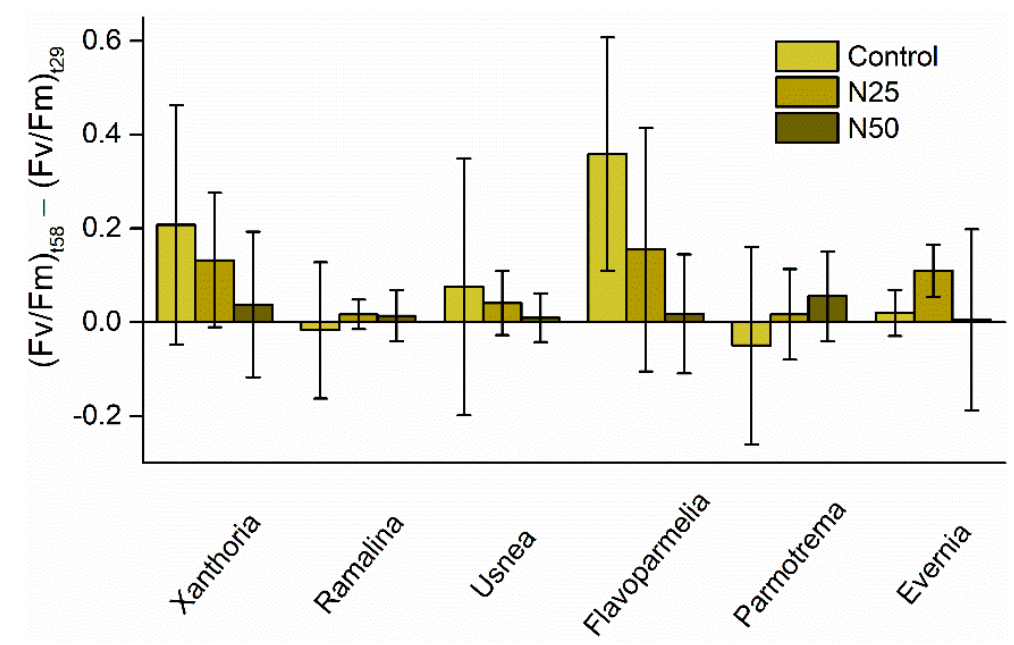

Figure 2. Recovery capacity for all studied lichens computed as the difference between $\mathrm{Fv} / \mathrm{Fm}$ ratio at the end of the experiment (day 58) and $\mathrm{Fv} / \mathrm{Fm}$ ratio at the end of the direct sunlight exposure (day 29) for the control (no nitrogen [N] addition), $25 \mathrm{~N}$ (treated with $25 \mathrm{mM}$ of $\left(\mathrm{NH}_{4}\right)_{2} \mathrm{SO}_{4}$ ), and $50 \mathrm{~N}$ (treated with $50 \mathrm{mM}$ of $\left.\left(\mathrm{NH}_{4}\right)_{2} \mathrm{SO}_{4}\right)$. No significant differences among $\mathrm{N}$ treatments were found for any species $(n=5)$.

Table 4. One-way ANOVA of the Fv/Fm evolution following the recovery period for all the studied epiphytic lichens.

\begin{tabular}{cccc}
\hline Lichen Species & df & F & $p$ \\
\hline Xanthoria parietina & 2 & 0.876 & 0.442 \\
Ramalina lacera & 2 & 0.304 & 0.743 \\
Usnea sp. & 2 & 0.280 & 0.761 \\
Flavoparmelia caperata & 2 & 2.379 & 0.135 \\
Parmotrema & 2 & 0.445 & 0.651 \\
hypoleucinum & 2 & 0.789 & 0.477 \\
Evernia prunastri & & & \\
\hline
\end{tabular}

\section{Discussion}

In general, our results showed a detrimental cumulative effect of $\mathrm{N}$ and solar radiation exposure on lichens but did not support the view that increased $\mathrm{N}$ availability constrained the physiological ability of lichens to cope with increased sunlight exposure, disproving our first hypothesis. However, in the case of Xanthoria, we found a differential response: It was unaffected by $\mathrm{N}$ addition, but solar exposure promoted an $\mathrm{N}$ dose-dependent response of the Fv /Fm parameter. Therefore, the physiological response of this species to increased $\mathrm{N}$ addition was modulated by solar radiation. Our second hypothesis, which states that different lichen species would vary in their response to the synergetic effect of increased $\mathrm{N}$ doses and solar exposure, was not supported by our data; we expected that the most tolerant species to each one of these environmental stressors, i.e., Xanthoria, would be the most resilient to their synergistic effect. In contrast to our expectations, we only found slight differences among species, as at the end of the combined treatment, Xanthoria was affected to the same extent as the rest of the analyzed species. Similarly, our last hypothesis was not supported because more tolerant functional groups were equally unable to recover after sunlight exposure as sensitive species.

These results indicate that a reduction of vitality among the epiphytic community should be expected in the face of global change. Increased $\mathrm{N}$ deposition that is projected to occur in the next decades in Mediterranean regions [9] has previously been pinpointed as a key factor underpinning reduced vitality in many epiphytic lichens [39]. Our data during 20 days of $\mathrm{N}$ addition, pre solar radiation, support this view, with reduced vitality in $\mathrm{N}$ sensitive species. Other researchers have found a fertilizing effect of moderate $\mathrm{N}$ supply 
shown by increased thalli $\mathrm{N}$, chlorophyll concentration, and rates of photosynthesis [21,40]. It is well documented that $\mathrm{N}$ performs as a nutrient below the toxicity threshold, especially in oligotrophic environments [41-43]. However, we did not observe this, possibly because the lichens came from a site with limited $\mathrm{N}$ contribution from surrounding roads and agricultural areas. Thus, even modest $\mathrm{N}$ addition doses during our experiment exceeded the fertilization threshold and performed as a pollutant.

Direct exposure to high solar radiation can also cause stress and threaten epiphytic lichens. Some lichens appear to be highly sensitive to sudden solar exposure increase [44], such as that observed in anthropogenically induced forest decline. This is despite the varied protective mechanisms lichens employ to avoid damage from high insolation such as colored cortical secondary compounds (e.g., usnic acid, parietin, and melanic compounds, [45,46]), thick cortical layer [47-49], hairiness [50], light-reflecting calcium oxalate crystals, or biochemical protective mechanisms [51]. A number of studies report a high natural radiation susceptibility of photosystem II in lichens [44,52], with particular sensitivity to both excessive ultraviolet (UV) [53] and photosynthetically active radiation [54]. Likewise, the increased temperature has also been highlighted as a major damaging factor for epiphytic lichen vitality. Smith and collaborators [55] found that warm climate tolerant lichen communities are already close to exceeding their upper climatic limits and are even more vulnerable to increased temperatures than high-elevation lichens. Our experimental design, which accounted for exposing wet lichens to direct solar radiation, does not allow us to discriminate between the effect of increased radiation and temperature. However, when Gauslaa and Solhaug [56] enclosed thalli of various lichens in a desiccator at $15{ }^{\circ} \mathrm{C}$ illuminated at $100 \mathrm{~mol} \mathrm{~m}^{-2} \mathrm{~s}^{-1}$, periodic measurements of $\mathrm{Fv} / \mathrm{Fm}$ showed a decreasing trend. They then removed all uppermost thalli exposed to the irradiance and measured thalli that had been shaded by the previously harvested thalli, finding that Fv/Fm values suddenly rose close to pre-desiccation levels (Gauslaa and Solhaug, unpublished data). Based on these findings, it is reasonable to think that the damaging factor operating in our experiment could be increased radiation more than temperature, although the interactive effect of both factors is also a plausible possibility. Accordingly, Gauslaa and Solhaug [57] reported a photoinhibition effect on lichen thalli due to heat and light stress both separately and combined.

Hydration status is a key determinant in how lichens respond to radiation. Wet thalli are more susceptible to irradiance than dried thalli because humidity increases the translucency of the protective upper cortex, increasing light absorbance [58,59]. Therefore, photosystem II needs more protection against the harmful excess light energy compared to desiccated thalli [60], in which case most of the radiation is reflected from the thalli surface [58]. Besides this generic aspect that might have had a role in the striking and undivided negative response of all studied lichens to solar radiation, hydration appears to deeply affect photoinhibition in a species-specific manner. Looking at the control thalli, the least affected by solar radiation was F. caperata. This could appear in contradiction with the fact that $F$. caperata is the only one among the species used in the experiment, adapted to diffuse light more than to direct solar radiation [26]. However, shade-adapted species were found to be most affected by radiation when they are dry, whereas sun-adapted species tend to be more susceptible when they are wet [56]. Tretiach et al. [61] showed that when hydrated, F. caperata activate repair mechanisms like ROS-scavenging enzymes and oxidation of polyols and phenols that allow it to survive in case of environmental stress. Since our samples were fully hydrated every day, we can reasonably argue that thalli could restore a proper enzymatic activity and antioxidants concentration daily [62]. In agreement, Gauslaa and Solhaug [56] observed that the sun-adapted X. parietina was less affected by radiation in its desiccated state, whereas hydration caused increased photoinhibition. These authors concluded that the extent of solar damage varies more among species when dry lichens are exposed to radiation than when radiation affects wet lichens. This, and the fact that all tested lichens shared a trebouxioid photobiont fully active following alternate wetting and drying cycles, could explain why we found such a homogeneous response to 
direct insolation among all studied species. Even more, this differential species-specific response to direct radiation responding to the hydration status could be the reason why we did not find the expected tolerance to radiation in Xanthoria when compared to shadeadapted species, as reported by other authors [26]. In other words, hydration status might be modulating the lichens species-specific response to excess irradiance.

The synergetic effect of $\mathrm{N}$ pollution and increased solar exposure (Table 2) did not differentiate between the lichens, but there were species response differences to $\mathrm{N}$ alone (Table 3). As expected, Xanthoria was the only species avoiding N-related physiological damage. It has been well established that X. parietina tolerates high atmospheric concentrations of ammonium in the field [16] and was physiologically unaffected when subjected to $\mathrm{NO}_{3}{ }^{-}$and $\mathrm{NH}_{4}{ }^{+}$excess in laboratory experiments [30,31]. Likewise, treatment with ammonium nitrate $50 \mathrm{mM}$ for 6 weeks did not cause any significant decrease in the $\mathrm{Fv} / \mathrm{Fm}$ parameter [39]. However, $\mathrm{N}$ does appear to have impaired the photosynthetic response to the secondary stress (Table 2). The highest $\mathrm{N}$ dose induced a decrease of the Fv/Fm ratio in Xanthoria responding to increased solar radiation when compared to the control and the lowest $\mathrm{N}$ dose (Figure 1). These results suggest that costly mechanisms to overcome harmful effects of increased solar irradiance might have compromised the lichen ability to make the needed investment in $\mathrm{N}$ tolerance. Nitrogen tolerance in lichens seems to be provided by constitutive characteristics $[63,64]$, but also by other inducible metabolic mechanisms $[43,65,66]$. The activation of such protective mechanisms comes at a cost, as shown by proteomic analysis in thalli of Cladonia portentosa: In thalli exposed to long-term $\mathrm{N}$ treatments, the ability to cope with increased $\mathrm{N}$ availability was related to an enhanced energetic metabolism [67]. In contrast, UV protection and tolerance to high solar radiation are provided by specific sunscreen compounds (e.g., usnic acid, phenolics, parietin [68-70]) and a general capacity to avoid and repair damages of oxidative stress [71]. As for $\mathrm{N}$ protection strategies, both the synthesis of secondary metabolites and antioxidant activities require energy [69]. Thus, Xanthoria could have spent more resources to respond to solar radiation, like the production of secondary compounds in the mycobiont, such as parietin, that can perform as regulators to avoid damage from high solar radiation [45,46], reducing other tasks. Nevertheless, we cannot unequivocally attribute this process to our results because measurements of secondary compounds would be needed to test this hypothesis.

As for the recovery capacity, in the light of the results shown in Figure 2 together with the bibliographic review, we deem the main part of the measured reduction in Fv/Fm values to be long-lasting photoinhibitory radiation damage. According to Solhaug and Gauslaa [72], a 2-day recovery period must be used to identify the more permanent longterm photoinhibitory damage to photosystem II in X. parietina, thus the 29-days recovery period used in our experiment is more than enough to classify this damage as permanent long-term. Such large depressions relative to start values responding to solar radiation in all species along with the lack of difference between species and $\mathrm{N}$ treatments in the recovery capacity, indicated that neither their functional groups nor the $\mathrm{N}$ treatments have a role in modulating the detrimental effect of solar radiation on epiphytic lichens. Gauslaa and Solhaug [56] observed that in some lichens, photosystem II is highly susceptible to solar radiation, preventing them from complete recovery even after extended recovery periods at low light that, according to Ögren [54], should allow recovery from photoinhibition.

\section{Conclusions}

Our results demonstrate the highly relevant consequences of the synergistic effects of $\mathrm{N}$ pollution and increased solar radiation for epiphytic lichens, likely moderated by the hydration status. Besides direct pollutant effects, the global change-driven forest decline promoting tree defoliation and death is likely to exacerbate the impact of $\mathrm{N}$ deposition on epiphytic lichens, making lichen species considered tolerant more prone to $\mathrm{N}$ pollution effects. Furthermore, the high susceptibility of photosystem II in epiphytic lichens should be taken into account in future studies on the synergetic effect of this environmental factor along with other global change drivers potentially inducing lichen damage. The loss 
of these organisms would likely have consequences for forest functions such as water retention, cycling of N, C, and P, as well as the provision of wildlife habitat [13]. Our results draw attention to the need to protect ecosystems from environmental drivers threatening canopy defoliation and tree death.

Supplementary Materials: The following are available online at https:/ /www.mdpi.com/article/10 .3390 /jof7050333/s1, Figure S1: Setup for the nitrogen treatment, Figure S2: Shelves containing the lichens during the experiment.

Author Contributions: Conceptualization, S.M. and L.M.; methodology, S.M. and L.M.; software, J.R.; validation, S.M., L.M., J.R., and C.C.; formal analysis, J.R.; investigation, L.M.; resources, C.C., L.M. and S.M.; data curation, L.M. and J.R.; writing-original draft preparation, L.M., J.R., and S.M.; writing-review and editing, S.M., L.M., J.R., and C.C.; visualization, L.M. and J.R.; supervision, C.C. and S.M.; project administration, L.M.; funding acquisition, L.M. All authors have read and agreed to the published version of the manuscript.

Funding: This research was funded by the European Union's Horizon 2020 research and innovation programme under grant agreement No 793965. The APC was funded by the European Union's Horizon 2020 research and innovation programme under grant agreement No 793965.

Institutional Review Board Statement: Not applicable.

Informed Consent Statement: Not applicable.

Data Availability Statement: The data presented in this study are openly available in FigShare at https:/ / doi.org/10.6084/m9.figshare.14473353.v1 (accessed on 15 March 2021).

Acknowledgments: We are grateful to Lucy Sheppard for language revision and useful insights.

Conflicts of Interest: The authors declare no conflict of interest.

\section{References}

1. Allen, C.D.; Breshears, D.D.; McDowell, N.G. On underestimation of global vulnerability to tree mortality and forest die-off from hotter drought in the Anthropocene. Ecosphere 2015, 6. [CrossRef]

2. Brouwers, N.C.; Mercer, J.; Lyons, T.; Poot, P.; Veneklaas, E.; Hardy, G. Climate and landscape drivers of tree decline in a Mediterranean ecoregion. Ecol. Evol. 2013, 3, 67-79. [CrossRef]

3. Lovett, G.M.; Weiss, M.; Liebhold, A.M.; Holmes, T.P.; Leung, B.; Lambert, K.F.; Orwig, D.A.; Campbell, F.T.; Rosenthal, J.; McCullough, D.G.; et al. Nonnative forest insects and pathogens in the United States: Impacts and policy options. Ecol. Appl. 2016, 26, 1437-1455. [CrossRef]

4. Brasier, C.M.; Robredo, F.; Ferraz, J.F.P. Evidence for Phytophthora cinnamomi involvement in Iberian oak decline. Plant Pathol. 1993, 42, 140-145. [CrossRef]

5. Oleksyn, J.; Przybyl, K. Oak decline in the Soviet Union-Scale and hypotheses. Eur. J. For. Pathol. 1987, 17, 321-336. [CrossRef]

6. Oak decline and the status of Ophiostoma spp. on oak in Europe. EPPO Bull. 1990, 20, 405-422. [CrossRef]

7. Delatour, C. Les dépérissements de chênes en Europe. Rev. For. Fr. 1983, 35, 265-292. [CrossRef]

8. Wardle, D.A.; Peltzer, D.A. Impacts of invasive biota in forest ecosystems in an aboveground-belowground context. Biol. Invasions 2017, 19, 3301-3316. [CrossRef]

9. Phoenix, G.K.; Hicks, W.K.; Cinderby, S.; Kuylenstierna, J.C.I.; Stock, W.D.; Dentener, F.J;; Giller, K.E.; Austin, A.T.; Lefroy, R.D.B.; Gimeno, B.S.; et al. Atmospheric nitrogen deposition in world biodiversity hotspots: The need for a greater global perspective in assessing N deposition impacts. Glob. Chang. Biol. 2006, 12, 470-476. [CrossRef]

10. Chave, J. The problem of pattern and scale in ecology: What have we learned in 20 years? Ecol. Lett. 2013, 16, 4-16. [CrossRef]

11. Levin, S.A. The problem of pattern and scale in ecology. Ecology 1992, 73, 1943-1967. [CrossRef]

12. Allen, C.D. Interactions across spatial scales among forest dieback, fire, and erosion in northern New Mexico landscapes. Ecosystems 2007, 10, 797-808. [CrossRef]

13. Berryman, S.; McCune, B. Estimating epiphytic macrolichen biomass from topography, stand structure and lichen community data. J. Veg. Sci. 2006, 17, 157-170. [CrossRef]

14. Stanton, D.E.; Huallpa Chávez, J.; Villegas, L.; Villasante, F.; Armesto, J.; Hedin, L.O.; Horn, H. Epiphytes improve host plant water use by microenvironment modification. Funct. Ecol. 2014, 28, 1274-1283. [CrossRef]

15. Matos, P.; Pinho, P.; Aragón, G.; Martínez, I.; Nunes, A.; Soares, A.M.V.M.; Branquinho, C. Lichen traits responding to aridity. J. Ecol. 2015, 103, 451-458. [CrossRef]

16. Pinho, P.; Dias, T.; Cruz, C.; Sim Tang, Y.; Sutton, M.A.; Martins-Loução, M.-A.; Máguas, C.; Branquinho, C. Using lichen functional diversity to assess the effects of atmospheric ammonia in Mediterranean woodlands. J. Appl. Ecol. 2011, 48, 1107-1116. [CrossRef] 
17. Pinho, P.; Llop, E.; Ribeiro, M.C.; Cruz, C.; Soares, A.; Pereira, M.J.; Branquinho, C. Tools for determining critical levels of atmospheric ammonia under the influence of multiple disturbances. Environ. Pollut. 2014, 188, 88-93. [CrossRef]

18. Giordani, P.; Brunialti, G.; Bacaro, G.; Nascimbene, J. Functional traits of epiphytic lichens as potential indicators of environmental conditions in forest ecosystems. Ecol. Indic. 2012, 18, 413-420. [CrossRef]

19. Chiarantini, L.; Rimondi, V.; Benvenuti, M.; Costagliola, P.; Di Benedetto, F.; Bardelli, F.; Cosio, C.; Lattanzi, P.; Sarret, G. Mercury speciation in Pinus nigra barks from Monte Amiata (Italy): An X-ray absorption spectroscopy study. Environ. Pollut. 2017, 227, 83-88. [CrossRef] [PubMed]

20. Loppi, S. May the diversity of epiphytic lichens be used in environmental forensics? Diversity 2019, 11, 36. [CrossRef]

21. Munzi, S.; Cruz, C.; Branquinho, C.; Cai, G.; Faleri, C.; Parrotta, L.; Bini, L.; Gagliardi, A.; Leith, I.D.; Sheppard, L.J. More tolerant than expected: Taking into account the ability of Cladonia portentosa to cope with increased nitrogen availability in environmental policy. Ecol. Indic. 2020, 119. [CrossRef]

22. Prentice, I.C.; Cramer, W.; Harrison, S.P.; Leemans, R.; Monserud, R.A.; Solomon, A.M. A global biome model based on plant physiology and dominance, soil properties and climate. J. Biogeogr. 1992, 19, 117-134. [CrossRef]

23. Geiser, L.H.; Jovan, S.E.; Glavich, D.A.; Porter, M.K. Lichen-based critical loads for atmospheric nitrogen deposition in Western Oregon and Washington Forests, USA. Environ. Pollut. 2010, 158, 2412-2421. [CrossRef]

24. Lavorel, S.; Garnier, E. Predicting changes in community composition and ecosystem functioning from plant traits: Revisiting the Holy Grail. Funct. Ecol. 2002, 16, 545-556. [CrossRef]

25. LIAS LIAS-A Global Information System for Lichenized and Non-Lichenized Ascomycetes. Available online: http://www.lias. net/ (accessed on 18 January 2021).

26. Nimis, P.L.; Martellos, S. ITALIC—The Information System on Italian Lichens; Version 5.0; University of Trieste, Dept. of Biology: Trieste, Italy, 1990.

27. Service, U.S.F. Air Pollution Sensitivity Ratings for Macrolichens in the US Pacific NW. Available online: http:/ / gis.nacse.org/ lichenair $/$ ?page=pnw_sensitivity (accessed on 18 January 2021).

28. Pinho, P.; Branquinho, C.; Cruz, C.; Tang, Y.S.; Dias, T.; Rosa, A.P.; Máguas, C.; Martins-Loução, M.-A.; Sutton, M.A. Assessment of critical levels of atmospheric ammonia for lichen diversity in cork-oak woodland, Portugal. In Atmospheric Ammonia: Detecting Emission Changes and Environmental Impacts; Springer: Dordrecht, The Netherlands, 2009; pp. 109-119, ISBN 9781402091209.

29. Gadsdon, S.R.; Dagley, J.R.; Wolseley, P.A.; Power, S.A. Relationships between lichen community composition and concentrations of NO2 and NH3. Environ. Pollut. 2010, 158, 2553-2560. [CrossRef] [PubMed]

30. Munzi, S.; Pisani, T.; Loppi, S. The integrity of lichen cell membrane as a suitable parameter for monitoring biological effects of acute nitrogen pollution. Ecotoxicol. Environ. Saf. 2009, 72, 2009-2012. [CrossRef] [PubMed]

31. Pirintsos, S.A.; Munzi, S.; Loppi, S.; Kotzabasis, K. Do polyamines alter the sensitivity of lichens to nitrogen stress? Ecotoxicol. Environ. Saf. 2009, 72, 1331-1336. [CrossRef] [PubMed]

32. Van Herk, C.M.; Mathijssen-Spiekman, E.A.M.; De Zwart, D. Long distance nitrogen air pollution effects on lichens in Europe. Lichenologist 2003, 35, 347-359. [CrossRef]

33. Veres, K.; Farkas, E.; Csintalan, Z. The bright and shaded side of duneland life: The photosynthetic response of lichens to seasonal changes is species-specific. Mycol. Prog. 2020, 19, 629-641. [CrossRef]

34. Raggio, J.; Green, T.G.A.; Sancho, L.G. In situ monitoring of microclimate and metabolic activity in lichens from Antarctic extremes: A comparison between South Shetland Islands and the McMurdo Dry Valleys. Polar Biol. 2016, 39, 113-122. [CrossRef]

35. Barták, M.; Hájek, J.; Gloser, J. Heterogeneity of chlorophyll fluorescence over thalli of several foliose macrolichens exposed to adverse environmental factors: Interspecific differences as related to thallus hydration and high irradiance. Photosynthetica 2001, 38, 531-537. [CrossRef]

36. Baruffo, L.; Tretiach, M. Seasonal variations of Fo, Fm, and F v/Fm in an epiphytic population of the lichen Punctelia subrudecta (Nyl.) Krog. Lichenologist 2007, 39, 555-565. [CrossRef]

37. Strasser, R.J.; Srivastava, A.; Tsimilli-Michael, M. The fluorescence transient as a tool to characterize and screen photosynthetic samples. In Probing Photosynthesis: Mechanisms, Regulation \& Adaptation; Yunus, M., Pathre, U., Mohanty, P., Eds.; Taylor \& Francis: London, UK, 2000; pp. 443-480. ISBN 0748408215.

38. Strasser, R.J.; Tsimilli-Michael, M.; Srivastava, A. Analysis of the fluorescence transient. In Chorophyll Fluorescence: A Signature of Photosynthesis, Advances in Photosynthesis and Respiration Series (Govindjee, Series Ed.); Papageorgiou, G.C., Govindjee, Eds.; Springer: Dordrecht, The Netherlands, 2004; pp. 321-362.

39. Munzi, S.; Pisani, T.; Paoli, L.; Loppi, S. Time- and dose-dependency of the effects of nitrogen pollution on lichens. Ecotoxicol. Environ. Saf. 2010, 73, 1785-1788. [CrossRef] [PubMed]

40. Sujetoviene, G.; Sliumpaite, I. Response of Evernia prunastri transplanted to an urban area in central Lithuania. Atmos. Pollut. Res. 2013, 4, 222-228. [CrossRef]

41. Carreras, H.A.; Gudiño, G.L.; Pignata, M.L. Comparative biomonitoring of atmospheric quality in five zones of Cordoba city (Argentina) employing the transplanted lichen Usnea sp. Environ. Pollut. 1998, 103, 317-325. [CrossRef]

42. Munzi, S.; Pisani, T.; Paoli, L.; Renzi, M.; Loppi, S. Effect of nitrogen supply on the C/N balance in the lichen Evernia prunastri (L.) Ach. Turkish J. Biol. 2013, 37, 165-170. [CrossRef]

43. Munzi, S.; Branquinho, C.; Cruz, C.; Loppi, S. Nitrogen tolerance in the lichen Xanthoria parietina: The sensitive side of a resistant species. Funct. Plant Biol. 2013, 40, 237-243. [CrossRef] 
44. Gauslaa, Y.; Solhaug, K.A. Differences in the susceptibility to light stress between epiphytic lichens of ancient and young boreal forest stands. Funct. Ecol. 1996, 10, 344-354. [CrossRef]

45. Fahselt, D. Secondary biochemistry of lichens. Symbiosis 1994, 16, 117-165.

46. Huneck, S. The significance of lichens and their metabolites. Naturwissenschaften 1999, 86, 559-570. [CrossRef]

47. Beckett, R.P.; Kranner, I.; Minibayeva, F. V Stress physiology and the symbiosis. In Lichen Biology, 2nd ed.; Cambridge University Press: Cambridge, UK, 2008; pp. 134-151. ISBN 9780521871624.

48. Gauslaa, Y.; Alam, M.A.; Lucas, P.-L.; Chowdhury, D.P.; Solhaug, K.A. Fungal tissue per se is stronger as a UV-B screen than secondary fungal extrolites in Lobaria pulmonaria. Fungal Ecol. 2017, 26, 109-113. [CrossRef]

49. Váczi, P.; Gauslaa, Y.; Solhaug, K.A. Efficient fungal UV-screening provides a remarkably high UV-B tolerance of photosystem II in lichen photobionts. Plant Physiol. Biochem. 2018, 132, 89-94. [CrossRef]

50. Bianchi, E.; Benesperi, R.; Colzi, I.; Coppi, A.; Lazzaro, L.; Paoli, L.; Papini, A.; Pignattelli, S.; Tani, C.; Vignolini, P.; et al. The multi-purpose role of hairiness in the lichens of coastal environments: Insights from Seirophora villosa (Ach.) Frödén. Plant Physiol. Biochem. 2019, 141, 398-406. [CrossRef]

51. Gasulla, F.; Casano, L.; Guéra, A. Chlororespiration induces non-photochemical quenching of chlorophyll fluorescence during darkness in lichen chlorobionts. Physiol. Plant. 2019, 166, 538-552. [CrossRef] [PubMed]

52. Demmig-Adams, B.; Máguas, C.; Adams III, W.W.; Meyer, A.; Kilian, E.; Lange, O.L. Effect of high light on the efficiency of photochemical energy conversion in a variety of lichen species with green and blue-green phycobionts. Planta 1990, 180, 400-409. [CrossRef]

53. Day, T.A.; Neale, P.J. Effects of UV-B radiation on terrestrial and aquatic primary producers. Annu. Rev. Ecol. Syst. 2002, 33, 371-396. [CrossRef]

54. Ögren, E. The significance of photoinhibition for photosynthetic productivity. In Photoinhibition of Photosynthesis from Molecular Mechanisms to the Field; Baker, N.R., Ed.; Bios Scientific Publishers: Oxford, UK, 1994; pp. 433-447.

55. Smith, R.J.; Jovan, S.; McCune, B. Climatic niche limits and community-level vulnerability of obligate symbioses. J. Biogeogr. 2020, 47, 382-395. [CrossRef]

56. Gauslaa, Y.; Solhaug, K.A. Photoinhibition in lichens depends on cortical characteristics and hydration. Lichenologist 2004, 36, 133-143. [CrossRef]

57. Gauslaa, Y.; Solhaug, K.A. High-light damage in air-dry thalli of the old forest lichen Lobaria pulmonaria-Interactions of irradiance, exposure duration and high temperature. J. Exp. Bot. 1999, 50, 697-705. [CrossRef]

58. Ertl, L. Über die Lichtverhältnisse in Laubflechten. Planta 1951, 39, 245-270. [CrossRef]

59. Gauslaa, Y.; Solhaug, K.A. Fungal melanins as a sun screen for symbiotic green algae in the lichen Lobaria pulmonaria. Oecologia 2001, 126, 462-471. [CrossRef]

60. Heber, U.; Bilger, W.; Shuvalov, V.A. Thermal energy dissipation in reaction centres and in the antenna of photosystem II protects desiccated poikilohydric mosses against photo-oxidation. J. Exp. Bot. 2006, 57, 2993-3006. [CrossRef] [PubMed]

61. Tretiach, M.; Pavanetto, S.; Pittao, E.; di Toppi, L.S.; Piccotto, M. Water availability modifies tolerance to photo-oxidative pollutants in transplants of the lichen Flavoparmelia caperata. Oecologia 2012, 168, 589-599. [CrossRef]

62. Kranner, I.; Zorn, M.; Turk, B.; Wornik, S.; Beckett, R.P.; Batič, F. Biochemical traits of lichens differing in relative desiccation tolerance. New Phytol. 2003, 160, 167-176. [CrossRef] [PubMed]

63. Hauck, M. Ammonium and nitrate tolerance in lichens. Environ. Pollut. 2010, 158, 1127-1133. [CrossRef]

64. Munzi, S.; Cruz, C.; Maia, R.; Máguas, C.; Perestrello-Ramos, M.M.; Branquinho, C. Intra- and inter-specific variations in chitin in lichens along a N-deposition gradient. Environ. Sci. Pollut. Res. 2017, 24, 28065-28071. [CrossRef]

65. Munzi, S.; Loppi, S.; Cruz, C.; Branquinho, C. Do lichens have "memory" of their native nitrogen environment? Planta 2011, 233 , 333-342. [CrossRef]

66. Silberstein, L.; Siegel, B.Z.; Siegel, S.M.; Mukhtar, A.; Galun, M. Comparative studies on Xanthoria parietina, a pollution-resistant lichen, and Ramalina duriaei, a sensitive species. I. Effects of air pollution on physiological processes. Lichenologist 1996, 28, 355-365. [CrossRef]

67. Munzi, S.; Sheppard, L.J.; Leith, I.D.; Cruz, C.; Branquinho, C.; Bini, L.; Gagliardi, A.; Cai, G.; Parrotta, L. The cost of surviving nitrogen excess: Energy and protein demand in the lichen Cladonia portentosa as revealed by proteomic analysis. Planta 2017, 245, 819-833. [CrossRef]

68. Bjerke, J.W.; Lerfall, K.; Elvebakk, A. Effects of ultraviolet radiation and PAR on the content of usnic and divaricatic acids in two arctic-alpine lichens. Photochem. Photobiol. Sci. 2002, 1, 678-685. [CrossRef] [PubMed]

69. Gauslaa, Y.; Ustvedt, E.M. Is parietin a UV-B or a blue-light screening pigment in the lichen Xanthoria parietina? Photochem. Photobiol. Sci. 2003, 2, 424-432. [CrossRef] [PubMed]

70. Solhaug, K.A.; Gauslaa, Y. Secondary Lichen Compounds as Protection Against Excess Solar Radiation and Herbivores. In Progress in Botany 73; Lüttge, U., Beyschlag, W., Büdel, B., Francis, D., Eds.; Springer: Berlin/Heidelberg, Germany, 2012; pp. 283-304, ISBN 978-3-642-22746-2.

71. Beckett, R.P.; Solhaug, K.A.; Gauslaa, Y.; Minibayeva, F. Improved photoprotection in melanized lichens is a of fungal solar radiation screening rather than photobiont acclimation. Lichenologist 2019, 51, 483-491. [CrossRef]

72. Solhaug, K.A.; Gauslaa, Y. Parietin, a photoprotective secondary product of the lichen Xanthoria parietina. Oecologia 1996, 108, 412-418. [CrossRef] [PubMed] 